\title{
2-deoxyglucose selection system for Agrobacterium-mediated transformation of Solanum lycopersicon and Nicotiana tabacum plants
}

\author{
Abang Masli Dayang Izawati ${ }^{1}$, Mat Yunus Abdul Masani ${ }^{1 *}$, Ghulam Kadir Ahmad Parveez ${ }^{1}$, Ismail \\ Ismanizan $^{2}$
}

${ }^{1}$ Advanced Biotechnology and Breeding Centre, Malaysian Palm Oil Board (MPOB), No. 6, Persiaran Institusi,
Bandar Baru Bangi, 43000 Kajang, Selangor, Malaysia
${ }^{2}$ Institute of System Biology (INBIOSIS), Universiti Kebangsaan Malaysia, 43600 Bangi, Malaysia

*Corresponding author: masani@mpob.gov.my

\begin{abstract}
An alternative marker to antibiotic and herbicide genes, 2-deoxyglucose-6-phosphate phosphatase $\left(D O G^{R} 1\right)$ gene was used to produce transgenic tomato (Solanum lycopersicon) and tobacco plants (Nicotiana tabacum) via Agrobacterium-mediated transformation approach. A binary vector, pBIDOG with T-DNA cassette consists of CaMV35S-DOG 1 -nos was mobilized into Agrobacterium tumefaciens LBA4404 via electroporation and subsequently transformed into tomato and tobacco tissues. Selection of transformants of both plants was carried out by using $600 \mathrm{mg} / \mathrm{l}$ 2-deoxyglucose (2-DOG) as selection agent. 2-DOG resistant calli were regenerated into shoots and PCR analysis revealed that $75 \%$ and $71 \%$ of putative transgenic tomato and tobacco shoots were positive for $D O G^{R} 1$ gene, respectively. Southern blot analysis was carried out to confirm the integration of transgene. The expected $\sim 1.5 \mathrm{~kb}$ band was obtained to prove the integration of $D O G^{R} 1$ gene into the plant genome. Transgenic tomato and tobacco plants were successfully regenerated without any phenotypic changes when compared to wild-type plants. Therefore, this alternative selection system can be applied to other plant transformation systems to produce transgenic plants free from antibiotic and herbicide genes, especially for important economic crops. More importantly, this selection system does not lead to any extent hazard to human and animal that subsequently will improve public acceptance of future genetically modified products.
\end{abstract}

Keywords: $D O G^{R} 1$ gene, 2-deoxyglucose, transgenic tomato and tobacco, Agrobacterium-mediated transformation.

Abbreviations: $D O G^{R} 1 \_2$-deoxyglucose-6-phosphate phosphatase; 2-DOG_2-deoxyglucose; IAA_indole-3-acetic acid; BAP_6benzylaminopurine; PCR_polymerase chain reaction; MS_Murashige and Skoog medium; CaMV35S_cauliflower mosaic virus $35 \mathrm{~S}$ promoter; CM_cultivation medium; nptII_neomycin phosphotransferase II gene; bp_base pair; kb_kilobase pair; NAA_ $\alpha$ naphthalene acetic acid.

\section{Introduction}

Tomato belongs to Solanaceae family (Vincentz et al., 2004) and was initially classified into the genus lycopersicon and the species esculentum. Based on molecular phylogenetic studies, tomato has been renamed Solanum lycopersicum (Peralta et al., 2006). Tomato is a very important food, and therefore it has been successfully bred to improve productivity and fruit quality, involving resistant to abiotic and biotic stresses. In addition, tomato has been widely used as a model plant and research material due to its special features such as fleshy fruit, sympodial shoots and compound leaves which other model plants such as rice and Arabidopsis do not have. These traits are agronomical important and cannot be studied using other model plant systems. Tomato has a very low chromosomal imbalance, high transformation frequency through Agrobacterium-mediated transformation of cotyledons (Barry et al., 2005; Thompson et al., 1999) and extensive cDNA and genomic libraries (Bonnema et al., 1996; Budiman et al., 2000). Tomato plants grow at high density and only take approximately three to four months for the fruit to reach full ripeness after germination, making it technically possible to obtain a large amount of tissue and study several generations in a short time.
Tobacco is a beautiful model plant system and often used for manipulating DNA in plants research. Some scholars have referred tobacco as the "white mouse" of the plant kingdom and sometime known as a keystone of solanaceous plant. The Solanaceae is a family of plant species that includes potato, tomato and tobacco with diverse phenotypes that have been exploited for a wide range of agronomic purposes (Rensink et al., 2007). Tobacco has both advantages and drawbacks. One advantage is the increased environmental and human safety. As from the aspect of containment, transgenic tobacco is either harvested before reaching maturity or tops are cut so that the transgenic tobacco does not flower. These practices can minimize the gene flow. Tobacco is a non-food crop, and thus chances of contaminating the food supply are minimal (Watson et al., 2004). One drawback of producing biologics in tobacco is that the tobacco biomass has to be processed immediately after harvest. Nevertheless, tobacco has been a useful model plant in transgenic studies. Numerous transgenic studies have been reported using the system. For example, the tobacco plant gene were altered by using the Lc regulatory gene (encodes homologous transcripts) which affects the formation of anthocyanin in plants. The flower 
color of the transgenic tobacco plants was changed from light red to deep red (Chi-Chun et al., 2007).

It is important to find an effective and efficient selection system for transgenic plants which carry genes coding for important traits (AGBIOS, 2003). Selectable markers enable transgenic plants or cells to be distinguished, isolated and selectively regenerated into a whole plant after transformation. The expression of a selectable marker gene results in a product that allows the survival of the transformed cells in the presence of a selective agent but prevents the regeneration of the non-transformed cells (Brasileiro and Dusi, 1999). The most common selection markers are the genes that confer resistance to herbicides, e.g. Basta and bialaphos and antibiotics, e.g. kanamycin and hygromycin (Tuteja et al., 2012). The use of genes for antibiotic and herbicide resistance is undesired in the crops relating to food industry. As such, an intensive search for other selectable markers such as positive selectable markers has been initiated and carried out. For the commercialization of transgenic plants, the use of positive selectable marker is desirable. Replacement of antibiotic resistant genes or other marker genes eliminates the negative connotations associated with these markers and would simplify the regulatory process (Malnoy et al., 2007).

One of the potential positive selectable markers is $D O G^{R} 1$ gene isolated from yeast Saccharomyces cerevisiae strain S288C (Randez-Gil et al., 1995). The $D O G^{R} 1$ encoding 2deoxyglucose-6-phosphate phosphatase gene can convert 2DOG-6-phosphate derived from phosphorylation of 2deoxyglucose (2-DOG) to non-toxic products. The 2-DOG-6phosphate is a toxic product resulting cell death by blocking protein synthesis and subsequently reduced polysaccharide synthesis, which is very important for cell wall formation (Zemek et al., 1976). This mechanism has been applied in regeneration of transgenic plants such as tomato, tobacco, potato (Kunze et al., 2001) and oil palm (Izawati et al., 2015) by selecting the $D O G^{R} 1$ transformed cells on medium containing 2-DOG.

In this study, the effects of 2-DOG on plant regeneration of tomato and tobacco were first investigated to identify the optimal concentration 2-DOG for selection of transformants. The efficient of 2-DOG as a selection agent was then evaluated by regenerating transgenic tomato and tobacco plants by Agrobacterium-mediated transformation approach.

\section{Results and Discussion}

\section{Effect of 2-DOG concentration for tomato explant culture}

To determine beforehand the 2-DOG concentration needed for selection of putative transformed tomato shoots, twenty cotyledons were cultivated on media supplemented with 2DOG ranging from 0-600 mg/l (Table 1). Percentage of shoot production was calculated based on the number of shoots appeared from number of cultured explants (cross-cut cotyledons). In general, almost $100 \%$ of explants produced shoots at concentrations of $0-200 \mathrm{mg} / \mathrm{l}$. The shoot production decreased from $60-25 \%$ at $300-500 \mathrm{mg} / \mathrm{l}$. At $400 \mathrm{mg} / \mathrm{l}, 500$ $\mathrm{mg} / \mathrm{l}$ and $600 \mathrm{mg} / \mathrm{l}$, shoots were produced at $35 \%, 25 \%$ and $0 \%$, respectively. These concentrations are suitable to be used for selection due to the low ability of explants to produce shoots. Based on visual observation, a normal growth of callus and shoots from tomato explants was observed at concentrations of 0-300 mg/l (Fig. 2). Even though calli were produced at 400 and $500 \mathrm{mg} / \mathrm{l}$, the shoots formed were retarded. The formation of callus and shoots was fully retarded at concentration of $600 \mathrm{mg} / \mathrm{l}$ (Fig. 2). Previous study by Kunze et al. (2001) showed that the optimal concentration of 2-DOG to select transformed tomato explants (Solanum lycopersicum Mill. cv. Moneymaker) was 400-500 mg/l. The discrepancy between the results obtained in the present study and the study by Kunze et al. (2001) was probably due to the different cultivars or varieties used.

\section{Effect of 2-DOG concentration for tobacco explants culture}

As for the tomato above, 2-DOG at the concentrations ranging from $0-600 \mathrm{mg} / \mathrm{l}$ was tested on wild-type leaf explants of tobacco (Table 1). A total of 25 tobacco leaf discs were tested and the number of shoots appeared from the cultured explants was scored. At $0-300 \mathrm{mg} / \mathrm{l}, 100 \%$ of leaf disc produced shoots while at $500 \mathrm{mg} / \mathrm{l}$ and $600 \mathrm{mg} / \mathrm{l}$, the shooting percentage decreased to $20 \%$ and $0 \%$, respectively. At $400 \mathrm{mg} / \mathrm{l}$, shoot formation was at $72 \%$ revealed that the ability of these tissues to form shoots was still high at this concentration. Therefore, the concentration is not suitable for selection of the transformed tissues because it is hard to differentiate the transformed from the untransformed tissues. The effects of different concentrations of 2-DOG is demonstrated in Fig. 2. The production of shoots from the calli was faster at $0-200 \mathrm{mg} / \mathrm{l}$ compared at $300-500 \mathrm{mg} / \mathrm{l}$ and fully retarded at concentration $600 \mathrm{mg} / \mathrm{l}$. It can be seen by blackish colour of the tobacco explants at $600 \mathrm{mg} / \mathrm{l}$.

Research by Kunze et al. (2001) showed that the lowest concentrations resulting in a nearly complete inhibition of regeneration of tobacco ( $N$. tabacum L cv Samsun NN) was at $500-600 \mathrm{mg} / \mathrm{l}$. Besides tomato and tobacco, 2deoxyglucose was also tested against other explants. Kunze et al. (2001) and Masli et al. (2012) reported that the regeneration of wild-type potato and oil palm calli were fully retarded at $300-500 \mathrm{mg} / \mathrm{l}$ and $400 \mathrm{mg} / \mathrm{l}$, respectively. Potato explants are more sensitive to 2-DOG compared to tobacco and tomato because their growth can be fully inhibited at as low as $300 \mathrm{mg} / \mathrm{l}$. For tobacco and tomato, the effective inhibitory concentration is much higher. The results showed that different plants have different sensitivity to 2-DOG or compound used in the media. Similar behavior was also observed for other selection agents such as kanamycin and mannose. For example, $50 \mathrm{mg} / \mathrm{l}$ of kanamycin was suitable to select transformed sweet potato (Ipomoea batatas cv. Lizixiang) (Sheng-Jun et al., 2004), while $200 \mathrm{mg} / \mathrm{l}$ kanamycin was used to select transformed tobacco leaf disc (Mentewab and Steward, 2005). Apple young leaves required $2.5,5$ and $10 \mathrm{~g} / \mathrm{l}$ of mannose for their selection (Degenhardt et al., 2006) while for the transformation of mature embryoderived calli of Indica rice (Oryza sativa L.), $30 \mathrm{~g} / \mathrm{l}$ of mannose was required (Penna et al., 2008).

\section{Optimal 2-DOG concentration for selection of transgenic tomato and tobacco}

For both explants (tomato and tobacco) used in this study, the possibilities of escapes are still high when the transformed explants were selected on media supplemented with 2-DOG at concentrations of $400 \mathrm{mg} / \mathrm{l}$ and $500 \mathrm{mg} / \mathrm{l}$. Escapes are defined as plants that are regenerated on selection medium without expressing the selectable marker gene (Gallois and Marinho, 1995). Based on the result from the present study, 2-DOG at a concentration less than $600 \mathrm{mg} / \mathrm{l}$ was probably still low. Selection agent at an insufficient concentration could promote chimeras (Masani et al., 2014; Parveez et al., 2015; Izawati et al., 2015). Therefore, as a precaution to minimize escapes and to narrow down the amount of transformed tissues to be analyzed, $600 \mathrm{mg} / \mathrm{l}$ of 2-DOG was 
Table 1. Effects of different concentrations of 2-DOG ranging from $0-600 \mathrm{mg} / \mathrm{l}$ on the regeneration of leaf explants of $N$. tabacum and $S$. lycopersicum.

\begin{tabular}{lcccccc}
\hline $\begin{array}{l}\text { 2-DOG } \\
(\mathrm{mg} / \mathrm{L})\end{array}$ & \multicolumn{3}{c}{$\begin{array}{c}\text { N. tabacum } \\
\text { (tobacco) }\end{array}$} & \multicolumn{3}{c}{$\begin{array}{c}\text { S. lycopersicum } \\
\text { (tomato) }\end{array}$} \\
\hline & Total $^{\mathrm{a}}$ & Shoots $^{\mathrm{b}}$ & $\%$ & Total $^{\mathrm{a}}$ & Shoots $^{\text {b }}$ & $\%$ \\
0 & 25 & 25 & 100 & 20 & 20 & 100 \\
100 & 25 & 25 & 100 & 20 & 20 & 100 \\
200 & 25 & 25 & 100 & 20 & 12 & 60 \\
300 & 25 & 25 & 100 & 20 & 9 & 45 \\
400 & 25 & 18 & 72 & 20 & 7 & 35 \\
500 & 25 & 5 & 20 & 20 & 5 & 25 \\
600 & 25 & 0 & 0 & 20 & 0 & 0 \\
\hline${ }^{a}$ Total number of explants tested. ${ }^{\mathrm{b}}$ Number of explants developing shoots & & & & & \\
\end{tabular}

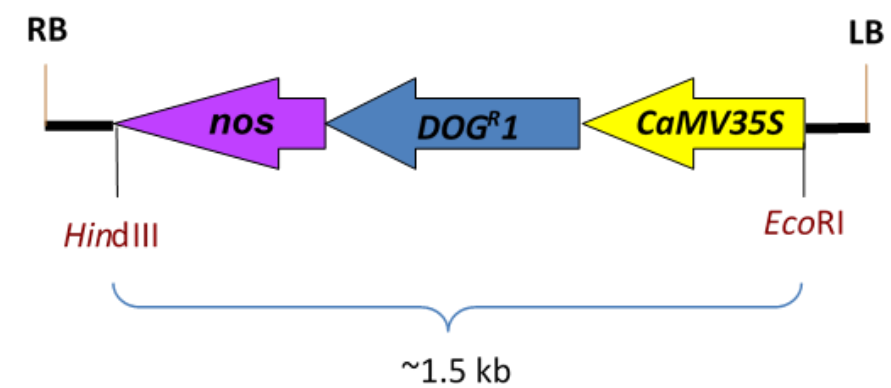

Fig 1. Map of DNA region containing $D O G^{R}$ lexpression cassette inserted between T-DNA borders of pBIDOG (reproduced from Izawati et al., 2015). RB_right border; LB_left border; nos_nopaline synthase terminator; DOG $G_{1}$ _gene codes for 2-DOG-6-P phosphatase; $35 S_{-}$CaMV35S promoter. Arrows indicate direction of transcription. The T-DNA was digested at the restriction sites (HindIII and EcoRI) for southern blot analysis.

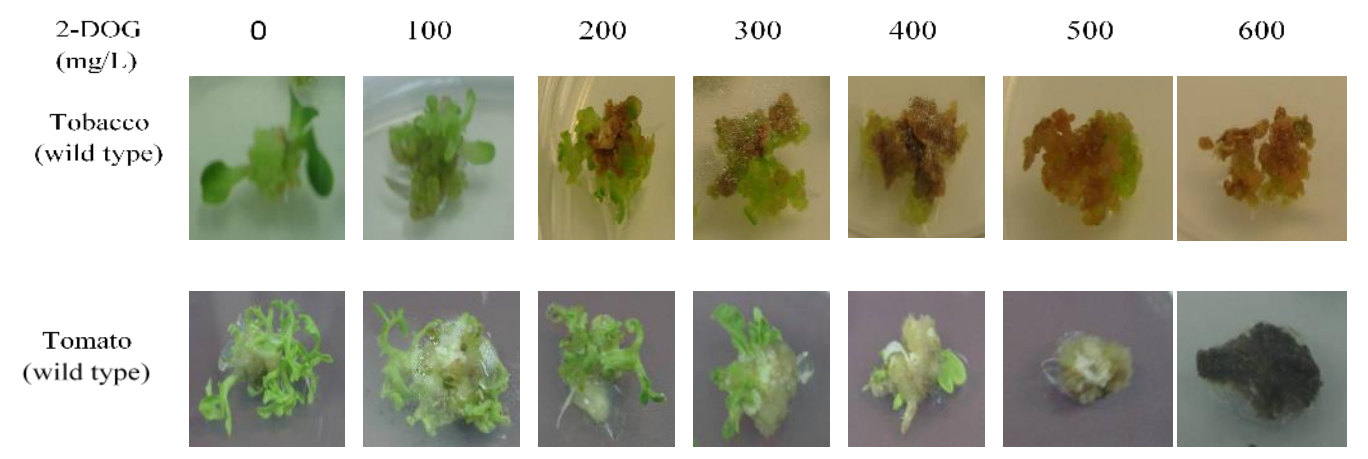

Fig 2. Effect of different concentrations of 2-DOG on tomato and tobacco tissues. Wild-type leaf explants of tobacco and tomato were cultured onto medium containing 2-DOG with concentrations ranging from 0-600 mg/l. At 0-300 mg/l, calli and shoots from tomato and tobacco explants were shown to have a normal growth. At 400 and $500 \mathrm{mg} / \mathrm{l}$, calli were produced but shoots formed were retarded. At concentration of $600 \mathrm{mg} / \mathrm{l}$, formation of calli and shoots was fully retarded.

chosen for selection of transformants from both tissues. Even though plants could become necrosis at this concentration, the chosen concentration is still acceptable as it will simplify the work to differentiate the transformed and untransformed tissues.

\section{Tomato transformation, selection and regeneration}

The protocol for Agrobacterium-mediated transformation and regeneration of transgenic tomato selected on 2-deoxyglucose medium is described below. Sterilized tomato seeds were germinated to obtain cotyledons (Figs. $3 \mathrm{~A}$ and 3B). Cotyledons of 10-14 days old tomato seedlings were crosscut into two pieces and used as the target tissues for the transformation (Fig. 3C). In tissue culture, young leaf is more suitable for callus induction because it has actively young dividing cells. When the young leaves are placed in suitable callus induction medium, the cells will continue to divide and form callus. For example, Rao et al. (2004) stated that the percentage of callus induction and regeneration were higher in the young leaves compared to mature leaves of Physalis pubescens L. In this work, callus appeared at the cut ends of tomato explants after 4-8 weeks on MSO medium supplemented with indole-3-acetic acid (IAA) and zeatin (Fig. 3D). Transformed calli were selected from selection medium which contained $600 \mathrm{mg} / \mathrm{l}$ of 2-DOG (Fig. 3E). Resistant calli started to propagate into bigger callus (Fig. 3F). Primary shoot or shoot bud started to appear from 

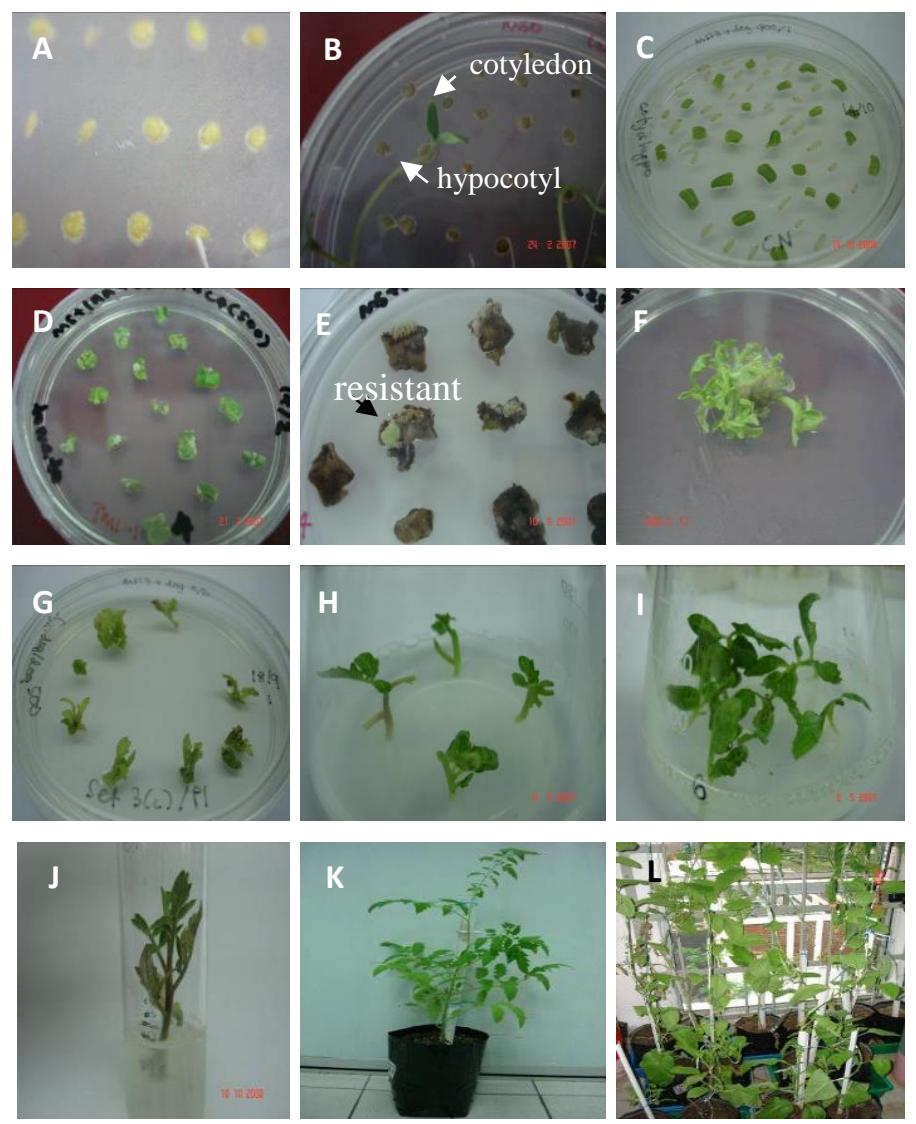

Fig 3. Development and regeneration of transgenic tomato plants. A: Germination of tomato seeds; B: cotyledons and hypocotyls; C: cut cotyledons; D: calli emerged from cut cotyledons; E: resistant calli on selection media; F: shoots appeared from calli; G and H: shoot development; I and J: root development; K and L: tomato plants in soil.
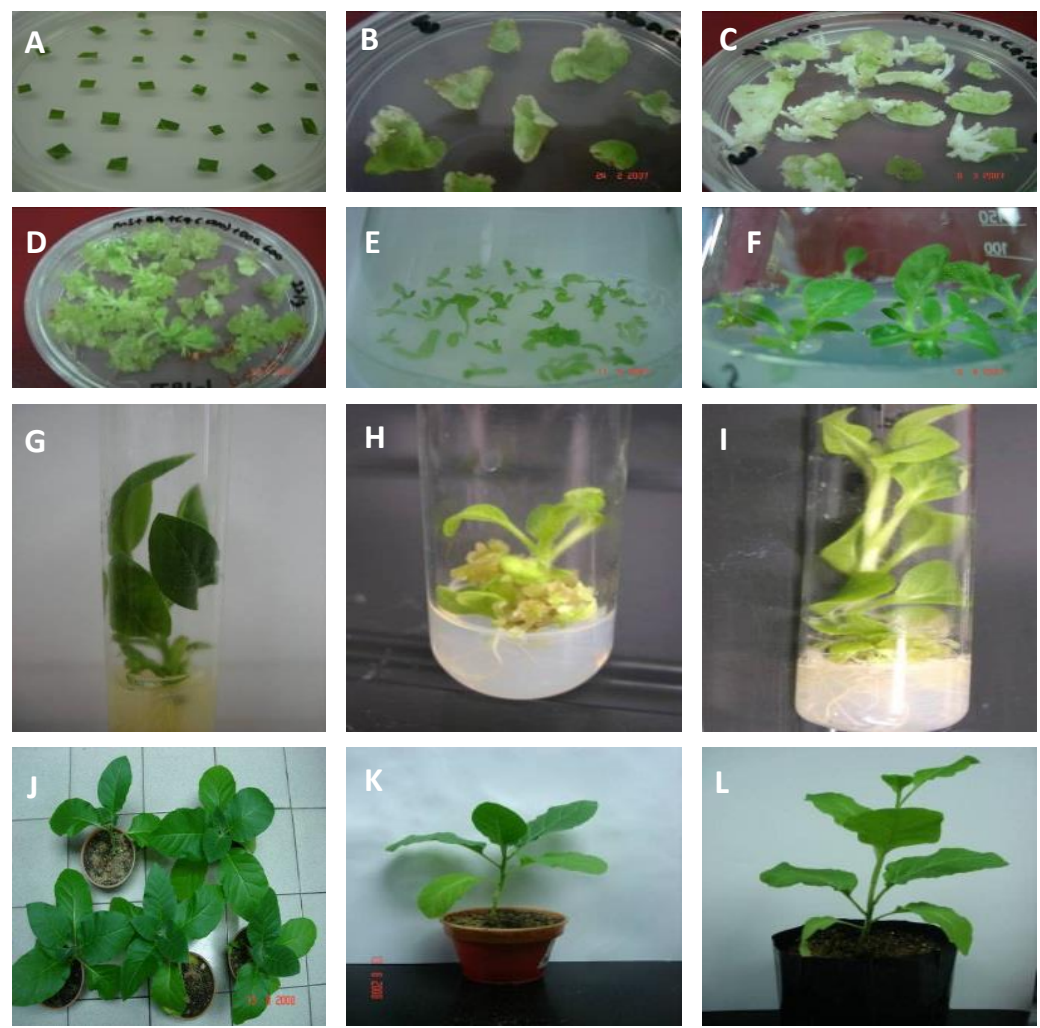

Fig 4. Development and regeneration of transgenic tobacco plants. A: tobacco leaf discs; B: expanded leaf disc and calli appeared at the edge of leaf; C and D: shoots at early formation stage; E and F: shoot development; G-I: tobacco plantlets at rooting stage; J-L: tobacco plants in soil. 

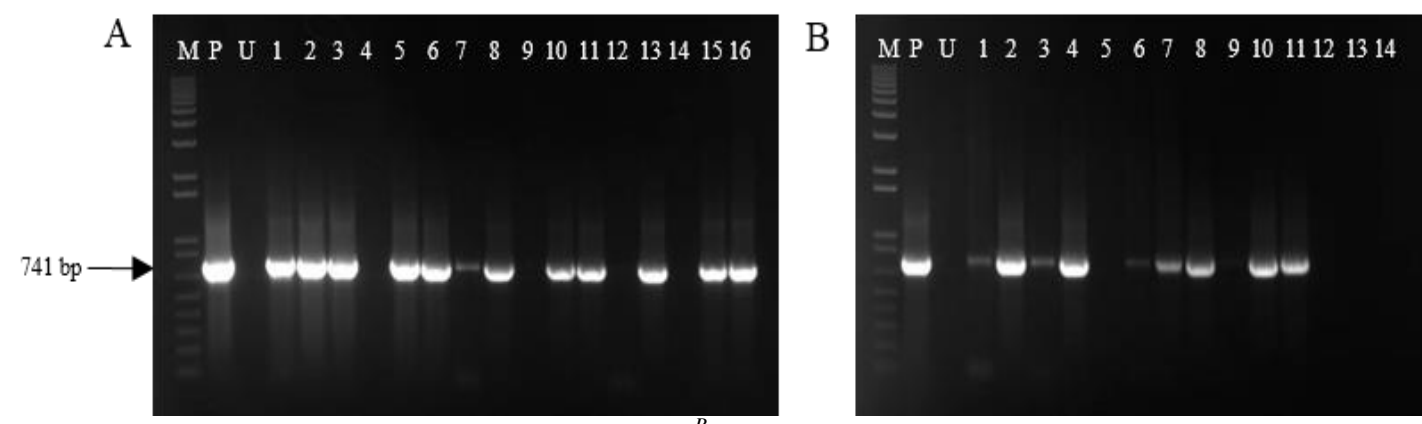

Fig 5. PCR analysis for the amplification of the $741 \mathrm{bp} D O G^{R} 1$ transgene from putative transgenic tomato (A) and tobacco (B) plants. Lane M: $1 \mathrm{~kb}$ plus marker; lane P: plasmid pBIDOG; lane U: untransformed control plant (wild-type plants); lanes 1-16 in (A): tomato shoots; lanes 1-14 in (B): tobacco shoots.

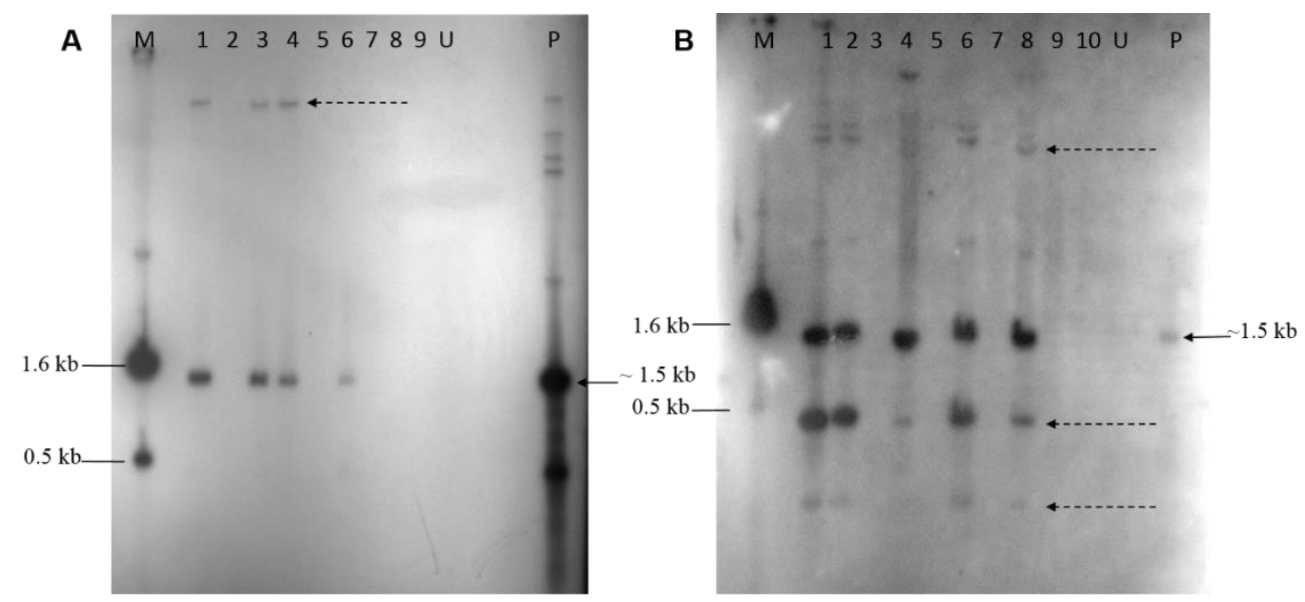

Fig 6. Southern analysis of tomato (A) and tobacco (B) genomic DNA samples which were digested with HindIII and EcoRI. Lane M: $1 \mathrm{~kb}$ plus marker; lane U: untransformed control plant (wild-type plant); lane P: plasmid pBIDOG; lanes 1-9: genomic DNA from putative transgenic tomato shoots in (A); lanes 1-10: genomic DNA from putative transgenic tobacco shoots in (B).
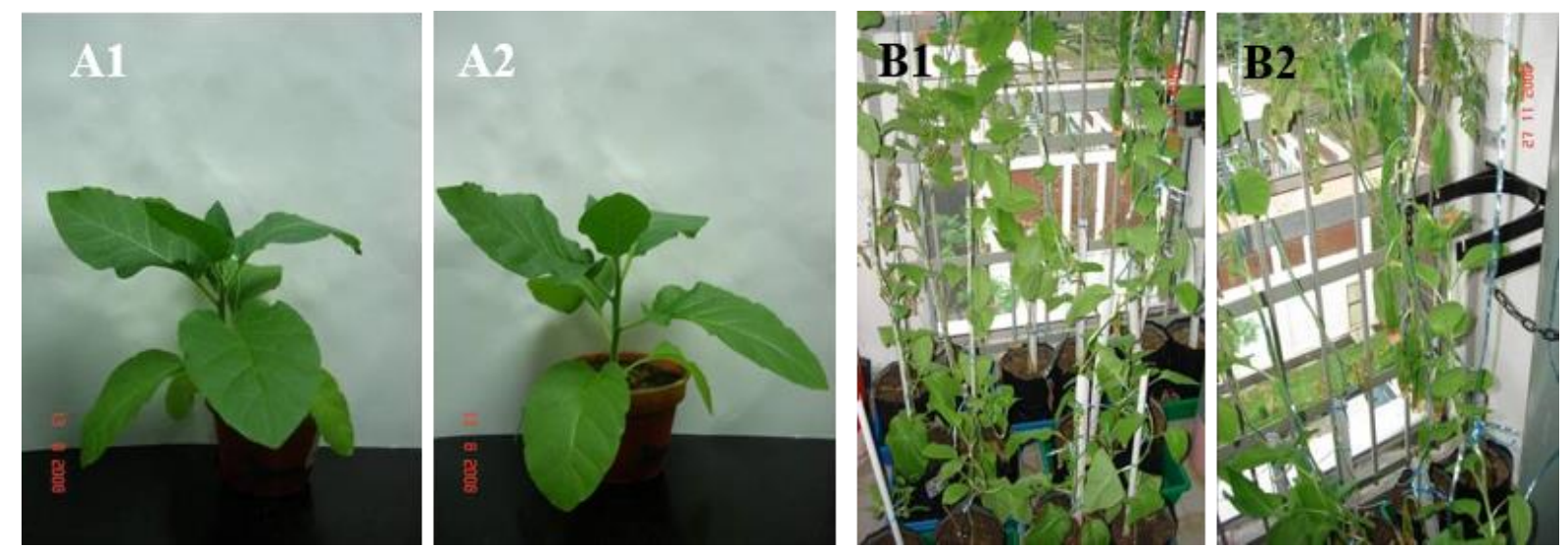

Fig 7. Comparison between transgenic and wild-type plants. A1: Transgenic tobacco; A2: wild-type tobacco; B1: transgenic tomato; B2: wild-type tomato.

transformed callus after 12-16 weeks (Fig. 3G). The shoots were transferred onto medium without hormone to promote better growth of shoots (Figs. 3H and 3I) and roots (Fig. 3J). Plantlets with strong shoots $(\sim 15 \mathrm{~cm}$ height $)$ and roots were transferred onto small pots $(12 \mathrm{~cm})$ covered with plastic, containing compose and vermiculite $(1: 1)$. The plantlets were maintained in growth chamber under a light/dark regime of $16 \mathrm{hr} / 8 \mathrm{hr}$ at $22-25^{\circ} \mathrm{C}$. After $2-3$ weeks, the plantlets were repotted into polybag $(20 \mathrm{~cm})$ containing soil, compose and vermiculite (3:3:1) and maintained in screen house (Fig. 3K). Normal transgenic tomato plants were fully regenerated from selected 2-DOG-resistant calli in several months (Fig. 3L).

\section{Tobacco transformation, selection and regeneration}

Leaf disc transformation of tobacco is a very simple and widely used with success in many laboratories. Basically, it involves immersing the leaf discs into a liquid culture of Agrobacterium carrying the chosen transformation vector. The infected leaf discs (Fig. 4A) were co-cultivated onto MS medium consisted of 6-benzylaminopurine (BAP) as a growth regulator to induce calli. The medium was also supplemented with antibiotic (cefotaxime) to kill the Agrobacterium and $600 \mathrm{mg} / \mathrm{l}$ of $2-\mathrm{DOG}$ to select 
tranformants from the untransformed cells. In plant tissue culture, calli are defined as undifferentiated mass cells that cover a plant wound (Stobbe et al., 2002). In this study, calli appeared at the cut ends of expanded tobacco leaf discs and other wounded parts of explants that occurred during the preparation of the explants for Agrobacterium infection (Figs. $4 \mathrm{~B}$ and $4 \mathrm{C}$ ). The cultures were placed under dark condition because darkness was found to be more conducive to callus production than either low or high light intensities (Teixeira da Silva et al., 2006). It took about a month for the calli to form primary shoots (Fig. 4D). Once the shoots appeared, the cultures were placed under light condition to promote photosynthetic process for better growth of the shoots (Figs. $4 \mathrm{E}$ and $4 \mathrm{~F}$ ). It took about two more months to develop rooted plantlets (Figs. 4G-4I). Plantlets with strong shoots and roots were transferred onto small pots (Figs. 4J and 4K). The plantlets were maintained in growth chamber under a light/dark regime of $16 \mathrm{hr} / 8 \mathrm{hr}$ at $22-25^{\circ} \mathrm{C}$. After $2-3$ weeks, the plantlets were repotted into polybag containing soil, compose and vermiculite (3:3:1) (Fig. 4L). A total of 14 putative transgenic tobacco plants were regenerated and maintained in screen house.

\section{Molecular analyses of putative transgenic plants}

PCR analysis was performed to detect $D O G^{R} 1$ gene in the genomic DNA of putatively transformed plants. The detection of expected 741 bp amplified product corresponding to the full-length $D O G^{R} 1$ gene, confirmed the presence of the transgene. A total of 12 out of 16 randomly selected tomato shoot samples showed the positive band while in 14 tobacco samples tested, 10 samples were positive (Fig. 5). No band was observed in untransformed plants. Based on PCR results, the transformation frequency for tomato and tobacco is estimated at about $75 \%$ and $71 \%$, respectively. The transformation frequency of tobacco in this study was slightly higher compared to study from Kunze et al. (2001), who demonstrated that $60-70 \%$ of 2-DOG resistant tobacco shoots harbored the $D O G^{R} l$ gene. Meanwhile for potato, Kunze et al. (2001) demonstrated that only $25 \%$ of transgenic plants were PCR positive for the $D O G^{R} l$ gene. The result shows that the transformation frequency based on 2-DOG selection system varies among plant species. For reliable verification, southern blot analysis is certainly needed to prove the integration of the transgene into tomato and tobacco genome. Therefore, randomly chosen genomic DNA of PCR-positive were digested with EcoRI and HindIII and hybridized with a CaMV35S-DOG ${ }^{R} 1$ nos fragment (Fig. 1). After hybridization, it was observed that only 5 out of 10 transformed DNA samples showed hybridization to the expected $1.5 \mathrm{~kb}$ band (Fig. 6). No signal was observed on untransformed sample (Lane U). Based on the DNA digestion profile, the $\sim 1.5 \mathrm{~kb}$ band was expected to correspond to the CaMV35S-DOG 1 -nos fragment. This hybridization with expected band size demonstrates the integration of the transgene into plant genome. Positive signals were detected at lanes of 1, 3, 4 and 6 for transformed tomato samples (Fig. 6A) and lanes of 1, 2, 4, 6 and 8 for tobacco samples (Fig. 6B) as well as lane $\mathrm{P}$ for positive control plasmid pBIDOG. No signal was observed in untransformed sample (Lane U). Additional bands (dash arrows) were also observed probably due to the same EcoRI and HindIII site or caused by the partial digestion of EcoRI and HindIII site in the genomic DNA (Fig. 6).

\section{Phenotype study of mature transgenic plants expressing $D_{O G}{ }^{R} 1$ gene}

Expression of $D O G^{R} 1$ gene in transgenic plants is not expected to cause any alteration in plant metabolism due to the narrow substrate specificity of the enzyme. The 2deoxyglucose (2-DOG) system was shown to work well in varieties of potatoes and was effective under field conditions. No phenotype differences could be found between the transgenic and the control plants (Kunze et al., 2001). This was true whereby the transgenic tomato and tobacco plants expressing $D O G^{R} l$ gene obtained in this work did not show any phenotypic differences when compared to wild-type or untransformed plants (Fig. 7)

\section{Materials and Methods}

\section{Plant material}

Tomato seeds of Solanum lycopersicon MT1 were surface sterilized by soaking in $20 \%(\mathrm{v} / \mathrm{v})$ sodium hypochlorite solution for $20 \mathrm{~min}$ followed by washing in sterile distilled water for 5 times. The sterile seeds were then placed on MSO medium [4.4 g/l MS salts (Murashige and Skoog, 1962), $\mathrm{R}_{3}$ vitamin (1 $\mathrm{g} / \mathrm{l}$ thiamine, $0.5 \mathrm{~g} / \mathrm{l}$ nicotinic acid, $0.5 \mathrm{~g} / \mathrm{l}$ pyridoxine), $30 \mathrm{~g} / \mathrm{l}$ sucrose, $\mathrm{pH} 5.9$ and $8 \mathrm{~g} / \mathrm{l}$ agar] and germinated in a growth chamber under a light/dark regime of $16 / 8 \mathrm{hr}$ at $25^{\circ} \mathrm{C}$. Meanwhile, In vitro culture plants of Nicotiana tabacum were cultured on MSO medium and placed under light/dark regime of $16 / 8 \mathrm{hr}$ at $25^{\circ} \mathrm{C}$.

\section{Determination of 2-DOG concentration on wild-type explants cultivation}

Tomato cotyledons from 10-14 days-old seedling were crosscut into two pieces $\left(\sim 1 \mathrm{~cm}^{2}\right)$ and cultured onto MSIZ medium [MSO medium, $0.1 \mathrm{mg} / \mathrm{l}$ indole-3-acetic acid (IAA), $1 \mathrm{mg} / \mathrm{l}$ zeatin] with increasing 2-DOG concentrations from 100 to $600 \mathrm{mg} / \mathrm{l}$. The explants were cultured onto fresh medium every 3 weeks and incubated under $16 / 8 \mathrm{hr}$ (light/dark) at $25^{\circ} \mathrm{C}$ for formation of callus and shoots. Once shoots appeared from the callus, the cultures were transferred onto MSO medium. On other hand, In vitro sterile tobacco young leaves were cut into small pieces $\left(1-2 \mathrm{~cm}^{2}\right)$ and transferred onto MSB medium [MSO medium, $1 \mathrm{mg} / \mathrm{l}$ 6benzylaminopurine (BAP)] with increasing 2-DOG concentrations (100-600 mg/l) and incubated under the same condition as tomato explants for callus and shoot development. The tobacco shoots were subcultured on MSO medium without BAP for maturation.

\section{Agrobacterium tumefaciens strain and vector}

Agrobacterium tumefaciens, strain LBA4404 harboring pBIDOG plasmid (Fig. 1) (Izawati et al., 2015) containing nptII (neomycin phosphotransferase) gene for bacterial selection and $D O G^{R} 1$ (2-deoxyglucose-6-phosphate phosphatase) gene as the plant selectable marker was used. The $D O G^{R} l$ gene was under the control of CaMV35S promoter.

\section{Preparation of Agrobacterium suspension}

About $50 \mu \mathrm{l}$ glycerol stock of Agrobacterium tumefaciens, LBA4404 which carries plasmid pBIDOG was cultured in 20 $\mathrm{mL}$ LB liquid medium containing $50 \mu \mathrm{g} / \mathrm{ml}$ kanamycin and $50 \mu \mathrm{g} / \mathrm{ml}$ rifampicin and incubated for 2 days. Two $\mathrm{ml}$ of the Agrobacterium culture were transferred into fresh $18 \mathrm{ml} \mathrm{LB}$ 
liquid medium and incubated for one and a half hours or until the optical density reached 0.5 to $0.6 \mathrm{~nm}$ prior to transformation.

\section{Plant transformation and regeneration of transgenic plants}

\section{Tomato}

Cotyledons from 10-14 days-old seedlings were cross-cut into two pieces and cultured on co-cultivation medium (CM) [MSO medium, $1 \mathrm{mg} / \mathrm{l}$ BAP, $0.1 \mathrm{mg} / \mathrm{l} \mathrm{NAA}(\alpha$-naphthalene acetic acid), $\mathrm{pH} 5.8$ ] for 1-2 days in dark condition prior to transformation. The explants were infected with Agrobacterium suspension by soaking for 2-3 min. After infection, the explants were dried on sterile filter paper, placed on $\mathrm{CM}$ medium, and then incubated at $28^{\circ} \mathrm{C}$ in the dark for 2-3 days. The explants were then transferred to regeneration medium (MSIZ) supplemented with $400 \mathrm{mg} / \mathrm{l}$ cefotaxime and incubated at $28^{\circ} \mathrm{C}$ in the dark for a week. Then, explants were transferred onto MSIZ medium supplemented with $200 \mathrm{mg} / \mathrm{l}$ cefotaxime and $600 \mathrm{mg} / \mathrm{l} \mathrm{2-}$ deoxyglucose [2-Deoxy-D-glucose Grade II (D8375), SigmaAldrich, St. Louis, USA] and incubated at $25^{\circ} \mathrm{C}$ with $16 / 8 \mathrm{hr}$ (light/dark). The explants were transferred to fresh medium every 3 weeks until shoots were formed. Regenerated shoots were further cultured on MSO medium containing $600 \mathrm{mg} / \mathrm{l}$ of 2-DOG for root induction. A duration of 5-6 months is required to regenerate rooted transgenic plantlets from the time of co-cultivation. Once roots were well established, the plantlets were transferred to soil for maturation.

\section{Tobacco}

Tobacco leaf discs were infected by soaking in the Agrobacterium suspension culture for 2-3 min. The inoculated leaf discs were dried on sterile filter paper and placed onto CM2 medium [MSO medium, $1 \mathrm{mg} / \mathrm{l} \mathrm{BAP]}$ at $28^{\circ} \mathrm{C}$ in the dark for 2-3 days. Next, the leaf discs were cultured onto CM2 medium supplemented with $400 \mathrm{mg} / \mathrm{l}$ of cefotaxime for a week. The explants were then transferred onto CM2 medium supplemented with $200 \mathrm{mg} / \mathrm{l}$ of cefotaxime and $600 \mathrm{mg} / \mathrm{l}$ 2-deoxyglucose (2-DOG) and cultured at $25^{\circ} \mathrm{C}$ in dark condition. Cultivation of explants was performed every 3 weeks until calli and shoots were formed. To induce shoot elongation and rooting, the explants were cultured onto MSO medium containing $600 \mathrm{mg} / \mathrm{l}$ of 2DOG. A duration of 3-4 months is required to regenerate rooted transgenic plantlets from the time of co-cultivation. Once roots were well established, the plantlets were transferred to soil compost and grown to maturity.

\section{Genomic DNA extraction, Polymerase Chain Reaction (PCR) and southern blot analyses.}

Genomic DNA was isolated from putative transgenic tomato and tobacco shoots by using the modified CTAB method (Doyle and Doyle, 1990). PCR analysis was performed to verify the presence of $D O G^{R} 1$ gene in the genomes of putative shoots. DNA was amplified using the $D O G^{R} l$ gene primers $\left(\mathrm{DOG}^{\mathrm{R}} 1\right.$ : 5'-ATGGATCCCCATGGCAGAATTTT CAGCTGATCTAT G-3' and DOG $^{\mathrm{R}}$ 2: 5'-ATGTCG ACTACTCAGGCCCTTGTCAAAGGGTTG-3'). Reaction conditions were as follows: the reaction mixtures were initially heated at $95^{\circ} \mathrm{C}$ for $5 \mathrm{~min}$. Then the amplification was performed in 10 cycles at $95^{\circ} \mathrm{C}$ for $1 \mathrm{~min}, 70^{\circ} \mathrm{C}$ for $1 \mathrm{~min}$ and $72^{\circ} \mathrm{C}$ for $1 \mathrm{~min}$. The annealing temperature was reduced by $1.7^{\circ} \mathrm{C}$ in each cycle. The reaction was continued in 25 cycles of $95^{\circ} \mathrm{C}$ for $1 \mathrm{~min}, 53^{\circ} \mathrm{C}$ for $1 \mathrm{~min}$ and $72^{\circ} \mathrm{C}$ for $1 \mathrm{~min}$. The reaction mixtures were subjected to a final extension of $72^{\circ} \mathrm{C}$ for $5 \mathrm{~min}$. PCR products were separated by electrophoresis in $1 \%(\mathrm{w} / \mathrm{v})$ agarose gels at $100 \mathrm{~V}$ and detected by ethidium bromide staining.

For southern blot analysis, $30 \mu \mathrm{g}$ of genomic DNA from putative transgenic plants were digested with EcoRI and HindIII and separated on 1\% agarose gel in 1XTBE buffer at $30 \mathrm{~V}$ overnight. The digested DNA was transferred onto nylon membrane (Amersham Hybond- $\mathrm{N}^{+}$) by capillary blotting (Sambrook et al., 1989). The nylon membrane was incubated overnight at $50^{\circ} \mathrm{C}$ in hybridization buffer $\left(0.5 \mathrm{M} \mathrm{Na}_{2} \mathrm{HPO}_{4}\right.$, $0.5 \mathrm{M} \mathrm{NaH}_{2} \mathrm{PO}_{4}, 0.5 \mathrm{M}$ EDTA pH 8.0, 7\% SDS $+\alpha^{32} \mathrm{P}-\mathrm{dATP}$ labelled probe). The radioactive labelled probe was prepared by using $1.5 \mathrm{~kb}$ DNA fragment CaMV35S-DOG ${ }^{R} 1$-nos extracted from pBIDOG plasmid by digestion with EcoRI and HindIII (Fig. 1). The membrane was washed with $2 \mathrm{X}$ $\mathrm{SSC} / 0.1 \% \mathrm{SDS}$ at $50^{\circ} \mathrm{C}$ for $10 \mathrm{~min}$ followed by $1 \mathrm{X} \mathrm{SSC} /$ $0.1 \% \mathrm{SDS}$ at $50^{\circ} \mathrm{C}$ for $10 \mathrm{~min}$. The membrane was exposed to an X-ray film (Kodak Photo Film) at $-70^{\circ} \mathrm{C}$ for 7 days. The film was visualized using the standard developer and fixer solutions (Kodak).

\section{Conclusion}

We successfully produced transgenic tomato and tobacco plants via Agrobacterium-mediated transformation using $D O G^{R} l$ gene as a selectable marker. We achieved moderate and acceptable transformation frequencies for both transgenic plants exhibiting normal phenotype demonstrated that the efficient of 2-DOG selection system. As an alternative to herbicides and antibiotics marker, this positive selection employing $D O G^{R} l$ gene can be used to develop a better selection system for other important crops such as rice and maize transformation. Recently, we have used 2-DOG selection system for oil palm transformation (Izawati et al., 2015) and experiments to improve the transformation rate are being intensively carried out.

\section{Acknowledgements}

The authors would like to thank the Director-General of MPOB for permission to publish this paper. The authors would like to acknowledge all members Transgenic Technology Group for their assistance. Thanks are also due to Dr. Omar Abdul Rasid of MPOB for critically reviewing the manuscript. This research was funded by Malaysian Palm Oil Board.

\section{References}

AGBIOS (2003) Biotech Crop Database. http://64.26.159.39/main.php. 12 June 2008.

Barry CS, McQuinn RP, Thompson AJ, Seymour GB, Grieson D, Giovannoni JJ (2005) Ethylene insensitivity conferred by the Green-ripe and Never-ripe 2 ripening mutants of tomato. Plant Physiol. 138(1):267-275.

Bonnema G, Hontelez J, Verkerk R, Zhang YQ, Van Daelen R, Van Kammen A, Zabel P (1996) An improved method of partially digesting plant megabase DNA suitable for YAC cloning: application to the construction of a 5.5 genome equivalent YAC library of tomato. Plant J. 9(1):125-133.

Brasileiro ACM, Dusi DMA (1999) Genetic transformation in plants. In: Torres AC, Caldas LS, Buso JA (ed) Tissue culture in plant genetic transformation. EmbrapaSPI/Embrapa-CNPH, Brazil. 679-735. 
Budiman MA, Mao L, Wood TC, Wing RA (2000) A deepcoverage tomato BAC library and prospects toward development of an STC framework for genome sequencing. Genome Res. 10(1):129-136.

Degenhardt J, Poppe A, Montag J, Szankowski I (2006) The use of the phosphomannose-isomerase/mannose selection system to recover transgenic apple plants. Plant Cell Rep. 25:1149-1156.

Chi-Chun Y, Jing-Juan Y, Qian Z, Deng-Yun Z, Guang-Ming A (2007) Influence of maize Lc regulatory gene on flower colour of transgenic tobacco and petunia. J Agri Biotechnol. 14(6):85-89.

Doyle JJ, Doyle JL (1990) Isolation of plant DNA from fresh tissue. Focus 12:13-15.

Gallois P, Marinho P (1995) Leaf disk transformation using Agrobacterium tumefaciens-expression of heterologous genes in tobacco. In: John $\mathrm{H}$ (ed) Plant gene transfer and expression protocols. Springer New York. 39-48.

Izawati AMD, Masani MYA, Parveez GKA, Ismail I (2015) Evaluation on the effectiveness of 2-deoxyglucose-6phosphate phosphatase $\left(\mathrm{DOG}^{\mathrm{R}} 1\right)$ gene as a selectable marker for oil palm (Elaeis guineensis Jacq.) embryogenic calli transformation mediated by Agrobacterium tumefaciens. Front Plant Sci. 6:727.doi:10.3389/fpls.2015.00727.

Kunze I, Ebneth M, Heim U, Geiger M, Sonnewald U, Herbers K (2001) 2-Deoxyglucose resistance: a novel selection marker for plant transformation. Mol Breed. 7:221-227.

Masani MYA, Noll GA, Parveez GKA, Sambanthamurthi R, Prüfer D (2014) Efficient transformation of oil palm protoplasts by PEG-mediated transfection and DNA microinjection. PLoS ONE 9(5): e96831.

Masli DIA, Parveez GKA, Ismail I (2012) Optimisation of 2deoxyglucose concentration for identifying the sensitivity level for oil palm embryogenic calli. J Oil Palm Res. 24:1296-1302.

Mentewab A, Stewart CN Jr (2005) Overexpression of an Arabidopsis thaliana $\mathrm{ABC}$ transporter confers kanamycin resistance to transgenic plants. Nat Biotech. 23(9):11771180.

Murashige T, Skoog F (1962) A revised medium for rapid growth and bio assays with tobacco tissue cultures. Physiol Plant. 15:473-497.

Malnoy M, Borejsza-Wysocka EE, Abbott P, Lewis S, Norelli JL, Flaishman M, Gidoni D, Aldwinckle HS (2007) Genetic transformation of apple without use of a selectable marker. Acta Hort. (ISHS) 738:319-322.

Parveez GKA, Rasid OA, Masani MYA, Sambanthamurthi R (2015) Biotechnology of oil palm: strategies towards manipulation of lipid content and composition. Plant Cell Rep. 34:533-543.
Penna S, Ramaswamy MB, Anant BV (2008) Mannose-based selection with Phosphomannose-Isomerase (PMI) gene as a positive selectable marker for rice genetic transformation. J Crop Sci Biotechnol. 11(4):233-236.

Peralta IE, Knapp S, Spooner DM (2006) Nomenclature for wild and cultivated tomatoes. Tomato Genet Coop Rep. 56:6-12.

Randez-Gil F, Blasco A, Prieto JA, Sanz P (1995) DOG ${ }^{\mathrm{R}}$ 1 and $\mathrm{DOG}^{\mathrm{R}} 2$ : two genes from Saccharomyces cerevisiae that confer 2-deoxyglucose resistance when overexpressed. Yeast 11(13):1233-1240.

Rao YV, Ravi Shankar A, Lakshmi TVR, Raja Rao KG (2004) Plant regeneration in Physalis pubescens L. and its induced mutant. Plant Tis Cult. 14(1):9-15.

Rensink WA, Lee Y, Liu J, Iobst S, Ouyung S, Buell CR (2005) Comparative analyses of six solanaceous transcriptomes reveal a high degree of sequence conservation and species-specific transcripts. BMC Genomics 6:124

Sambrook J, Fritsch EF, Maniatis T (1989) Molecular Cloning-A Laboratory Manual. Cold Spring Harbor, New York.

Sheng-Jun J, Qing-Chang L, Hong Z, Li-Sha W, Yu-Ping W (2004) Regeneration of sweet potato transgenic plants with oryzacystatin-I (OCI) gene. Chinese J Agri Biotechnol. 1:99-102.

Stobbe H, Schmitt U, Eckstein D, Dujesiefken D (2002) Developmental stages and fine structure of surface callus formed after debarking of living lime trees (Tilia sp.). Ann Bot. 89:773-782.

Thompson AJ, Tor M, Barry CS, Vrebalov J, Orfila C, Jarvis MC, Giovannoni JJ, Grierson D, Seymor GB (1999) Molecular and genetic characterization of a novel pleiotropic tomato-ripening mutant. Plant Physiol. 120(2):383-390.

Teixeira da Silva JA, Chan MT, Sanjaya, Chai ML, Tanaka M (2006) Priming abiotic factors for optimal hybrid cymbidium (Orchidaceae) PLB and callus induction, plantlet formation, and their subsequent cytogenetic stability analysis. Sci Hortic. 109:368-378.

Tuteja N, Verma S, Sahoo RK, Revendar S, Reddy IN (2012) Recent advances in development of marker-free transgenic plants: regulation and biosafety concern. J Biosci. 37(1):167-197.

Vincentz M, Cara FAA, Okura VK, Pedrosa GL (2004) Plant biologists evaluation of monocot and eudicot divergence using the sugarcane transcriptome 1. Plant Physiol. 134:951-959.

Watson J, Koya V, Leppla SH, Daniell H (2004) Expression of Bacillus anthracis protective antigen in transgenic chloroplasts of tobacco, a non-food/feed crop. Vaccine 22:4374-4384.

Zemek J, Stremen J, Hricová D (1976) Metabolism of 2deoxy-D-glucose in the yellow and the green spruce culture (Pices excelsa Link). Plant Physiol. 77:95-98. 